\title{
Is Accessibility of Internet Financial Reporting Evolving Towards More Compliance of Disclosure?
}

\author{
Anissa Windarti \\ Universitas Islam Negeri Syarif Hidayatullah Jakarta, Indonesia, anissa.windarti@uinjkt.ac.id
}

\begin{abstract}
Financial transparency is a demand of the community in the current era of information disclosure. Internet Financial Reporting (IFR) through e-government is the most effective media in disseminating information to the public. The purpose of this article is to analyze the effect of financial performance on compliance with financial information disclosure through accessibility of Internet Financial Reporting as moderating. The sample is determined by a purposive sampling technique that requires having e-government and a website that can be accessed until June 2018 and has a Financial Report for 2015-2016. The collected data is analyzed by using Moderated Regression Analysis. The finding is that financial performance (efficiency ratios, effectiveness ratios, routine expenditure ratios and development expenditure ratios) affected the compliance of financial information disclosures. The results of the Moderated Regression Analysis (MRA) also show that IFR accessibility variables are moderating variables between financial performance to compliance with financial information disclosures. This research provides empirical data about the relevance of IFR accessibility evolving towards more compliance of disclosure through e-government websites.
\end{abstract}

Keywords: regional government, financial performance, accessibility Internet Financial Reporting, financial disclosure

Acknowledgement: Thanks to the Research and Publishing Centre (Puslitpen) LP2M UIN Syarif Hidayatullah Jakarta, that has funded this research through the research grant.

\section{Introduction}

Regional governments are public sector organizations that have an obligation to account for the management of funds originating from the community. The public sector organization is required to show a more noteworthy degree of manageability, responsibility and straightforwardness in the utilization of open assets (Elkadi, 2013).

All forms of income and expenditure must be reported transparently to obtain public trust. This form of financial reporting is no longer published in print but through internet-based electronics 
known as Internet Financial Reporting (IFR). Regional governments publish their financial statements transparently through the websites of each region starting from the regency / city to the provincial level. Transparency is an expansive idea which is identified with the accessibility of data (supply side of transparency) what's more, the entrance and convenience of this data by residents, and partners (request side of transparency) (Araujo \& Romero, 2016).

Instruction of the Minister of Home Affairs No. 188.52 / 1797 / SJ / 2012 have regulated the components that must be reported on the official website of local government in Indonesia. There are many benefits to the existence of the Internet Financial Reporting (IFR). In addition to being efficient in terms of paper use, the existence of IFR also shortens the time and extends the acceptance of financial information to stakeholders widely. Even IFR becomes a medium for financial information disclosure (Khan \& Ismail, 2012). In other words, the existence of e-government will improve back-office operations and offer better, efficient and transparent $24 / 7$ services to citizens (Munyoka, 2019).

Achieving government performance efficiency through e-government will increase transparency so that it can promote clean governance. In this way, transparency encourages social orders to improve their administrations' sure commitments while likewise serving to take care of issues intrinsic to government movement (Guillamón et al, 2016).

The success of e-government is determined by many factors. These factors must be known to minimize the failure of implementing e-government, as happened in developing countries (Elkadi, 2013). Several factors that led to the failure of e-government were the prevailing of socio-economic hardships, bad governance and political instability (Munyoka, 2019). What's more, the planning and disclosure of financial information is expensive and it is a fixed expense for association or local government (Bolivar, Munoz \& Hernandez, 2013). One of the challenges faced by the government and society is how to build digital (or electronic) access canals that can be effectively used. In determining the type of canal access the ins and outs of technology familiar with the community must be considered. Thus, people's access to digital information determines the effectiveness of egovernment implementation in supporting government performance.

One measure of government performance is measured from the financial aspect. Based on the results of previous research, it shows that good financial performance will encourage local governments to disclose financial information to the public (Hiola, Rosidi \& Aji, 2016). Ahwan's research, et al. shows that good financial performance will encourage regional governments to disclose financial information to the public (Hadi, Handajani \& Putra, 2018). In order for the community to obtain financial information, reliable accessibility is needed. Accessibility in this case, the ease with which to obtain and view financial statements will greatly determine the arrival of this information to the public. There is no research on IFR which makes accessibility as a moderator between financial performance and compliance with financial information, disclosure. With good financial performance and a high level of accessibility, it is expected that regional governments will be more obedient in disclosing their financial information.

Thus, IFR accessibility will provide convenience for stakeholders to obtain financial information. The performance that has been achieved by the government can be displayed and reported through 
government websites and can be accessed by various layers of society. Therefore, this research will examine the effect of government performance on financial information disclosure, by being moderated by IFR accessibility variables. With this research, it is expected that regional governments can improve the quality of electronic services, so that transparency in regional financial management can also be improved.

\section{Research Question}

In short, this study seeks to determine the compliance level of financial information disclosure on official government websites. Can the financial performance and accessibility of IFR improve compliance with financial information disclosure, by taking case studies from provincial governments throughout Indonesia?

\section{Research Objectives}

Overall Objective

- to analyze the effect of financial performance on compliance with financial information disclosure through the accessibility of IFR as a moderator.

\section{Specific Objectives}

- to analyze the effect of financial performance on compliance with financial information disclosure.

- to analyze the effect of accessibility of IFR with financial information disclosure.

\section{Agency Theory and Signalling Theory}

In agency theory, it is stated that there are conflicts between principals and agents in the organization. Agency conflict also occurs in government organizations (Zimmerman, 1997). In this case, the community is the principal who gives its mandate to the government as an agent to achieve welfare goals. Communities will need information to evaluate the course of government. The community will also provide direct supervision on government performance. In this case, Guillamón, M.-D., et al. (2016) also revealed that the use of e-government will bring information closer to the public so that it can reduce agency costs because it is more transparent.

Signaling theory can describe the behavior when two parties (individuals or organizations) have access to different information (Conelly et al, 2011). The government as the bearer of the people's mandate will try to show its success in various programs that have been designed by providing information to the public. The government will give a good signal to the people (Styles \& Tennyson, 2007). This good signal is shown by the good performance achieved by the government, so that it will influence community support to the government. Government performance must be informed to the public as accountability as well as a form of promotion in politics (Hilmi \& Martani, 2012). Signals in the form of regional government quality information are communicated through the website as well as e-commerce (Mavlanova, Fich \& Kaufaris, 2012). 


\subsection{Financial Performance}

Performance is the work result that has been achieved from the implementation of an activity with the aim of achieving the organization's goals, objectives, vision and mission. The performance of public sector organizations can be broken down into various categories, such as financial measures. The financial performance achieved by local governments is a positive signal to get support from the community. Many researches use financial size categories in this research (Hadi, Handajani \& Putra, 2018; Hilmi \& Martani, 2012; Martani \& Lestiani, 2012; Puspita \& Martani, 2012; Verawaty, 2015; Mahsun, 2009).

The independence ratio is intended to measure the ability of regional governments to finance the administration of their own government by comparing locally-generated revenue (PAD) with central and provincial government subsidies and regional loans (Wau \& Ratmono, 2015).

The independence ratio is calculated by comparing the amount of PAD revenue divided by the amount of transfer income from the central and provincial governments and regional loans. The effectiveness ratio measures the level of output of public sector organizations towards public sector revenue targets (Mahsun, 2009). There are 4 categories of PAD effectiveness levels. Meanwhile, efficiency ratio shows the level of input from public sector organizations to the level of output of the public sector (Mahsun, 2009).

The activity performance ratio is part of the ratio of other legitimate PADs from other total Regional Revenue and Expenditures Budget (APBD). The activity ratio includes the routine expenditure ratio and the development expenditure ratio. The routine expenditure ratio is obtained by comparing the total routine expenditure with the total $\mathrm{APBD}$, while the development expenditure ratio is obtained by comparing the total development expenditure and the total APBD budget.

In previous researches, there are still varied results in terms of testing the effect of financial performance by compliance with disclosure of regional financial information on the internet. results of the Istikomah and Mutmainah research show that the dependency ratio has a negative effect on the publication of regional government financial statements through the internet (Istikomah \& Mutmainah, 2017). However, the results of Wau's research show that the regional financial independence ratio has a positive effect on access to financial information on government websites (Wau \& Ratmono, 2015). Similarly, the research results by Puspita and Martani which show that regional dependence (DAU) has a positive effect on disclosure of content and disclosure presentations (Puspita \& Martani, 2012). However, the ratio of PAD and Regional Expenditures did not affect the disclosure of content, presentation of disclosures and total disclosures on the regional government website (Puspita \& Martani, 2012). Based on the signaling theory, it can be hypothesized that local governments with good financial performance will increase compliance with information disclosure as a form of positive signals to get public support.

Hypothesis 1: The independence ratio affects the compliance of financial information disclosures

Hypothesis 2: Effectiveness ratio affects the compliance of financial information disclosures

Hypothesis 3:The Efficiency ratio affects the compliance of financial information disclosures 
Hypothesis 4: The routine expenditure ratio affects the compliance of financial information disclosures

Hypothesis 5: The development expenditure ratio affects the compliance of financial information disclosures

\subsection{E-Government}

According to Reffat, e-government is a transformation of government services to the public which is realized by not only displaying information on sites on the internet (Reffat, 2006). However, services in e-government must reach the transact stage not only by publishing and interacting. When a country has reached the transact stage, a transaction will occur that relates to the transfer of money from one party to another (Indrajit, 2002). For example e-Samsat facility that makes it easy for taxpayers to pay their vehicle tax online. This is a form of Government to Citizens or G2C relations. Government relations with its citizens have proven to be more democratic and transparent through e-government (Chen et al, 2006).

Disclosure of information through internet media (e-government) is the most efficient media in terms of the speed of information dissemination. However, the effectiveness of receiving this information is determined by IFR's accessibility. The easier it is for the public to access information from the internet, the easier it will be for people to evaluate government performance. When the government's performance is very satisfactory, this will have a positive impact to get support from the community. However, the results of the research by Nosihana and Yaya state that Leverage, regional revenue, type of Regional Government and audit opinion have not been proven to influence IFR practices in Regional Government (Nosihana \& Yaya, 2016). This proves that not all regions with good financial conditions will provide complete financial information on the official site of the regional government (Nosihana \& Yaya, 2016). The results of the Wau research also the financial independence ratio of regional governments had a positive effect on the access of financial information on government websites (Wau \& Ratmono, 2015).

Hypothesis 6: IFR accessibility affects the compliance of financial information disclosures

\subsection{Internet Financial Reporting Accessibility}

As a tool for public accountability, financial statements presented through the internet will bring regional financial management in a more transparent direction. Law No. 14 of 2008 article 9 concerning Public Information Openness becomes the legal protection for disclosure of financial information. Public information in the form of financial statements must be provided and announced periodically in accordance with the instruction of the Minister of Home Affairs of the Republic of Indonesia No. 188-52 / 1797SJ. With high accessibility, it is expected that the community will easily obtain financial information so that it will encourage the government to work more transparently and disclose financial information more fully. Styles and Tennyson state that cities with high income levels will provide financial reports on the internet and accessibility related to financial position (Styles \& Tennyson, 2007). Information on financial performance will be easier for the public to accept when there is reliable IFR accessibility. The public can use this financial 
information as an evaluation tool for public accountability, so that public support and trust in the government will increase. So that local governments will try to disclose financial information transparently through the internet.

Hypothesis 7: IFR accessibility can moderate the influence of the independence ratio on compliance with disclosure of financial information

Hypothesis 8: IFR accessibility can moderate the effect of effectiveness ratios on compliance with disclosure of financial information

Hypothesis 9: IFR accessibility can moderate the effect of efficiency ratios on compliance with disclosure of financial information

Hypothesis 10: IFR accessibility can moderate the effect of the ratio of routine expenditure on compliance with disclosure of financial information

Hypothesis 11: IFR accessibility can moderate the influence of the development expenditure ratio on compliance with financial information disclosures

\section{Methods}

This research is a type of quantitative research using data in the form of information from the regional government website and local government financial reports. The population used is all regional governments in Indonesia, amounting to 34 provincial governments. The sampling technique is using purposive sampling. Researchers will take samples with certain conditions or considerations, namely having e-government up to June 2018 and e-government is not in repair (maintenance) and has financial statements for 2015-2016.

The dependent variable in this research is compliance with disclosure of regional government financial information on the website. Disclosure of compliance is based on the scoring index list of the Ministry of Home Affairs, which is based on the Instruction of the Minister of Home Affairs No. 188.52 / 1797 / SJ / 2012. There are 12 documents that must be published in the management of the regional budget. Observation items include transparency content, summary of Work and Budget Plans (RKA) of Regional Work Units (SKPD), Summary of Work and Budget Plans (RKA) of Regional Financial Management Officers (PPKD), Draft on Local Regulation of regional revenue and expenditure budget (APBD), Draft on Amendment of Local Regulation of APBD, Local Regulation of APBD, Local Regulation of APBD Amendment, SKPD's Budget Implementation Document Summary (DPA), PPKD's Budget Implementation Document Summary (DPA), SKPD's Budget Realization Report (LRA), PPKD Budget Realization Report, Regional Government Financial Report (LKPD) which has been audited by the Audit Board of the Republic of Indonesia (BPK) and BPK Opinion on LKPD. The existence of these documents is assessed using a scale of 0 to 2 . The number 0 indicates if no document is found, number 1 indicates that the document exists but is incomplete and number 2 indicates that the document exists and is complete. Especially for transparency content using a scale of 0 and 1 . 
The independent variables in this research are financial performance which includes independence ratios, effectiveness ratios, efficiency ratios, activity ratios which consist of the ratio of routine expenditure to the APBD and the ratio of development expenditure to the APBD (Halim \& Damayanti, 2007). Financial ratios can be used as indicators of public sector performance measurement. The use of ratios in determining financial performance is not free from criticism because of weaknesses. As stated by Rusmin et al, the ratio analysis should be accompanied by the right proxy (Rusmin, Astami \& Scully, 2014). This inaccuracy can also be caused by differences in the selection of accounting policies that are tailored to the problems in each region with a variety of geographical characters, political status and regional size (Chaney, Mead, Schermann, 2002).

Independence Ratio = Total PAD / Total of transfer revenue of central government + loan

Effectiveness Ratio $=$ revenue target $/$ realization

Efficiency Ratio $=$ cost of PAD collecting $/$ realization of revenue from PAD

Routine Expenditure Ratio $=$ Total Routine Expenditure $/$ APBD Total

Development Expenditure Ratio = total development expenditure / total APBD

The moderating variable in this research is the accessibility of IFR as measured by IFFRACESS in the form of accessibility index value used in the Styles and Tennyson research (2007). Here is the Calculation of Accessibility Index which is the basis for assessing how many steps it takes to find the financial statement in the official website of local government.

Table 1. Calculation of Accessibility Index Value (Source: Styles and Tennyson, 2007)

Point A: +1 point if the official local government website or city a) appears on the first page of Google or Yahoo search by typing the name of the city or region.

b) Presents a summary financial statements in the form of concise tables or concise and easily accessible descriptions

Point $\mathrm{B}:+1$ point if the website a) provides more than one complete file with documents from financial statements

b) Presents a complete and comprehensive financial report component

Point C: +1 point if the financial report a) is in the form of HyperText Markup Language (HTML).

b) HTML forms a higher score than pdf format because information is easier and faster to access

Points D: +1 point if the official website a) provides financial information for the previous year.

b) IFLGR also presents the previous year's report for comparison

Point E: +1 if the website does not allow us to click more than three clicks to arrive at the previous report as a comparison. This indicates that website visitors gain easy access

e.g. IFLGR for the current year which is presented every semester so that it is always updated and on time.

Point F: +1 point if the official website a) provides information to obtain or access copies of financial reports of city or district governments 

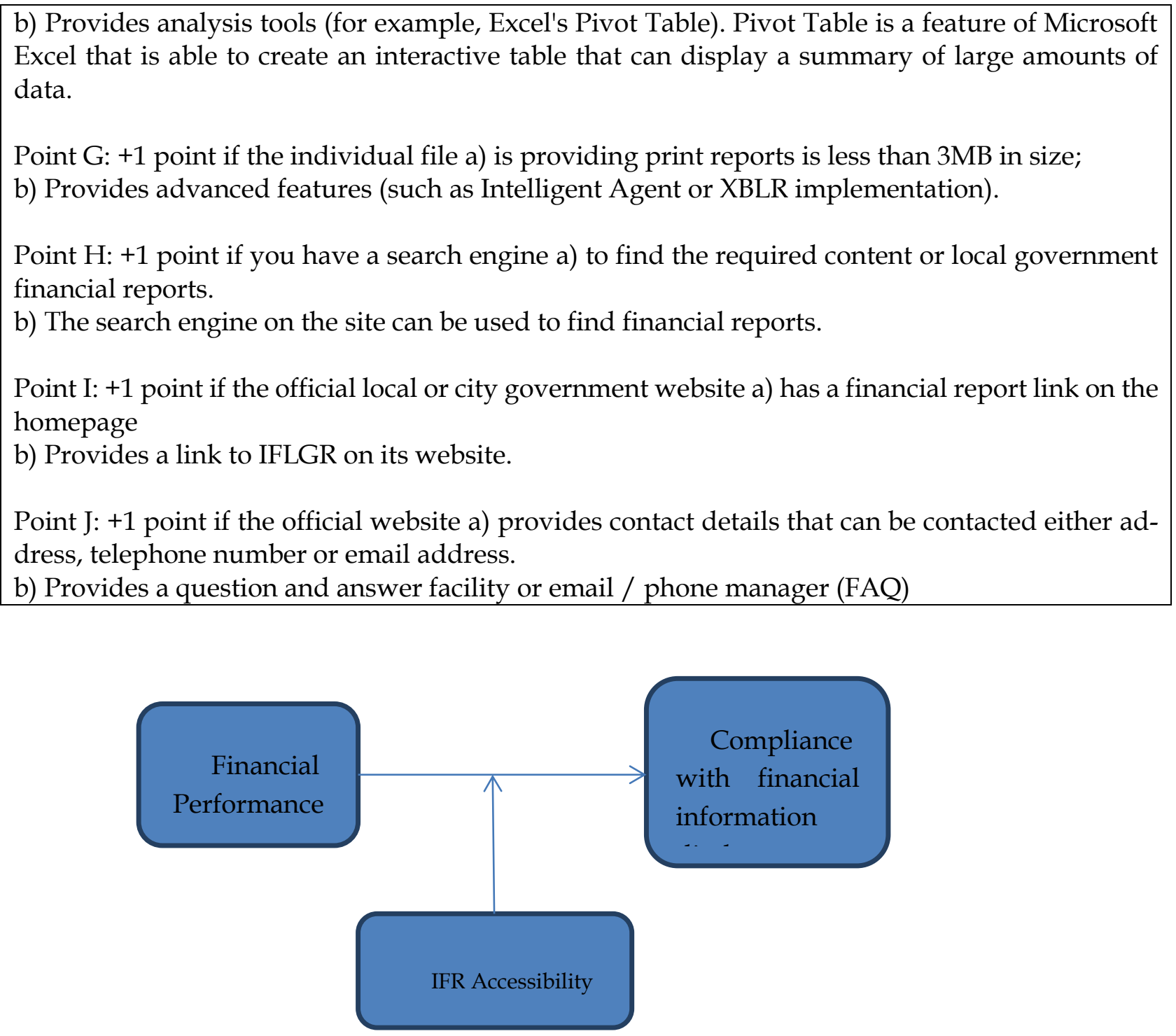

Figure 1: Research Variable Relationship

In this research, there are three variables, namely Financial Performance, IFR Accessibility and Disclosure Compliance (Figure 1). The independent variable of Financial Performance consists of independence ratio, effectiveness ratio, efficiency ratio, routine expenditure ratio and development expenditure ratio. While the position of the independent variable of IFR accessibility as moderating between the variables of Financial Performance and Compliance Disclosure.

To test the hypothesis, the regression analysis method is used with the moderating variable, namely the interaction test (Moderated Regression Analysis) with the following formula

$$
\mathrm{Y}=\mathrm{a}+\mathrm{b} 1 \mathrm{X} 1+\mathrm{b} 2 \mathrm{X} 2+\mathrm{b} 3 \mathrm{X} 1 \mathrm{X} 2+\mathrm{e}
$$

Explanation:

$\mathrm{Y}$ : Compliance with financial information disclosures 
a : constants

$\mathrm{X} 1$ : financial performance

$\mathrm{X} 2$ : IFR accessibility

In contrast to Wau's research that uses ordinal logistic regression and multiple linear regression methods in testing the factors that influence the availability and accessibility of IFR (Wau \& Ratmono, 2015).

Meanwhile, Verawaty's research uses comparative analysis between provincial governments in Indonesia (Verawaty, 2016). Chusna used a regression method to examine the effect of regional government size, regional government financial conditions, level of dependence, regional prosperity, and type of government on the level of disclosure of budget management information (Chusna, 2016).

\section{Analysis of Result}

To obtain a regression equation that is not biased, the data must be prerequisite to be tested in the form of a normality test and heterocedasticity test. Based on table 2, it can be seen that the magnitude of the Kolmogorov Smirnov value is 1.956 at the 0.001 significance level. This shows that the residual data is normally distributed. The results of this normality test are in accordance with the results of the P-Plot normality test. Based on the spread of the points around the diagonal line and following the direction of the diagonal line, it can be concluded that the residual data is normally distributed (figure 2). So it can be concluded that the regression model has met the normality assumptions.

Table 2. Test Result of Kolmogorov Smirnov

\begin{tabular}{ll}
\hline & $\begin{array}{l}\text { Unstandardized } \\
\text { Residual }\end{array}$ \\
\hline Kolmogorov-Smirnov & 1.956 \\
Asym.Sig. (2-tailed) & .001 \\
\hline
\end{tabular}

Normal P-P Plot of Regression Standardized Residual

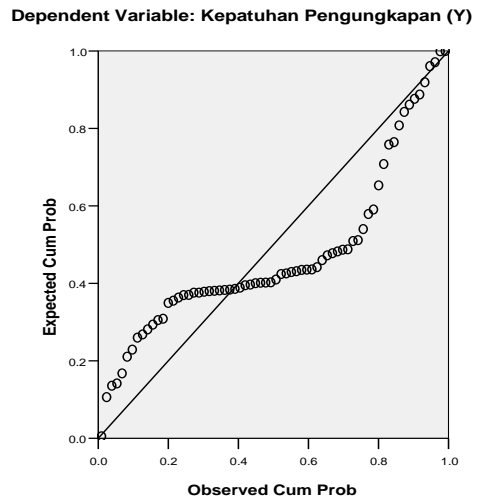


Figure 2: Test Result of P-Plot

Heterocedasticity test is used to find out whether in the regression model there is an inequality of variance from one residual observation to another. The Glejser test results in table 3 show that the significance values in the variables in this research are greater than 0.05 . With this $5 \%$ confidence level, it can be concluded that the regression model in this research does not contain heterocedasticity.

Table 3. Heteroscedasticity Test Results (Glejser Test)

\begin{tabular}{ll}
\hline Model & Sig \\
\hline Independence ratio & .110 \\
Effectiveness ratio & .823 \\
Efficiency ratio & .394 \\
Routine expenditure ratio & .776 \\
Development expenditure ratio & .760 \\
Accesibility IFR & .378 \\
Moderate__ndependence ratio & .112 \\
Moderate_Effectiveness ratio & .638 \\
Moderate_Efficiency ratio & .385 \\
Moderate_Routine expenditure ratio & .942 \\
Moderate__Development expenditure ratio & .968 \\
\hline
\end{tabular}

Based on table 4, it can be seen that the results of the Anova test or F test are 19.234 with a significance level of 0,000 . The significance level that is far below 0.05 indicates that the regression model can be used to predict disclosure compliance. So that it can be concluded that the Financial Performance variable in the form of independence ratio, effectiveness ratio, efficiency ratio, routine expenditure ratio and development expenditure ratio, and IFR and Moderate accessibility variables jointly influence the Disclosure Compliance.

Table 4. Test Results of Simultaneous Significance

\begin{tabular}{llll}
\hline Model & F & Sig. & Conclusion \\
\hline Regression & 19.234 & .000 & Effected \\
\hline
\end{tabular}

In table 5, it can be seen that the Independent Ratio variable has a parameter coefficient value of 0.007 with a significance level of 0.534 . The significance value is above 0.05 so it can be concluded that the Independence Ratio does not affect the compliance of financial information disclosures. Thus, H1 in this research was not accepted. This result is not in accordance with the results of Wau's research which shows that the regional financial independence ratio has a positive effect on the access of financial information on government websites (Wau \& Ratmono, 2015). Similarly, the results of the research by Puspita and Martani which show that regional dependence (DAU) has a positive effect on disclosure of content and disclosure presentations (Puspita \& Martani, 2012). From the results of this study it can be seen that local governments have not been optimal in presenting local financial information to the public. Transparency in the form of disclosing financial information via the internet has not become the main thing in providing performance information to the public. Local governments should respond quickly to information needs without having to rely on funds 
from the central government, because the closer performance information is to the public, the greater public support for local governments will be.

Table 5. Result of Hypothesis Test

\begin{tabular}{llll}
\hline Model & $\mathbf{t}$ & Sig & Conclusion \\
\hline Independence ratio & .625 & .534 & Not accepted \\
Effectiveness ratio & -2.625 & .011 & Accepted \\
Efficiency ratio & 4.043 & .000 & Accepted \\
Routine expenditure ratio & 4.848 & .000 & Accepted \\
Development expenditure ratio & -4.799 & .000 & Accepted \\
Accesibility IFR & .239 & .812 & Not accepted \\
Moderate_Independence ratio & -.770 & .444 & Not accepted \\
Moderate_Effectiveness ratio & 2.584 & .012 & Accepted \\
Moderate_Efficiency ratio & -4.146 & .000 & Accepted \\
Moderate_Routine expenditure ratio & -5.365 & .000 & Accepted \\
Moderate_Development expenditure & 5.318 & .000 & Accepted \\
ratio & & & \\
\hline
\end{tabular}

From the results of this research, it can be seen that high performance regional governments do not automatically disclose financial information through the internet. The parameter coefficient value of the Effectiveness Ratio variable is -0.220 with a significance of 0.011 . The significance value of 0.011 is smaller than at 0.05 so that it can be concluded that the Effectiveness Ratio affects the compliance of financial information disclosures. The results of this study indicate that the local government has optimized or exploited the potential revenue in the region. With the existing creativity and innovation, the regions will be able to achieve the budgeted revenue targets. This achievement requires monitoring and evaluation so that local governments transparently disclose their financial information to the public.

In the third hypothesis, the Efficiency Ratio variable is estimated to affect the compliance of financial information disclosures. After being statistically tested, the hypothesis was proven empirically based on the test results in table 4 . The coefficient value of variable parameter of Efficiency Ratio was 0.186 with a significance level of 0.000 . The results of this study indicate that the local government has been able to minimize costs incurred to earn revenue and optimize the realization of revenue received in order to improve regional financial efficiency. Local governments have realized that this financial performance information is a positive signal that the public needs to know as accountability for regional budget management and transparency in the use of fees.

In the fourth hypothesis, it is stated that the ratio of routine expenditure affects the compliance of financial information disclosures. Empirically, the hypothesis can be accepted according to the results of statistical tests in table 4 . The value of variable parameter coefficient of Routine Expenditure Ratio is 0.002 with a significance level of 0.000 . In the regional budget, routine expenditure posts have a fairly large cost allocation because they are used to finance expenses such as employee salaries, purchasing equipment, etc. The high allocation for routine expenditure items requires supervision and evaluation from the public, so the demands for financial transparency must be met 
by local governments. Financial information in the budget realization report is published and can be accessed by the public.

Seeing the results of the hypothesis test in table 4, there is a coefficient value of variable parameter of Development Expenditure of -0.010 and the significance level at the level of 0.000 . This shows that the significance value is far below 0.05 so that $\mathrm{H} 5$ in this research is acceptable. So it can be concluded that the ratio of development expenditure affects the compliance of financial information disclosures. The development expenditure ratio is still at a level below the routine expenditure ratio, which means that development spending is not yet a top priority in the regional budget. This development expenditure post includes regional development financing such as the construction of public facilities and infrastructure. Transparency and evaluation are urgently needed by the public to control the use of this development budget, so that financial information in the budget realization report is needed by the public. Therefore, the local government strives to meet the demands of the community as a form of accountability to the public.

The results of this research also indicate that financial performance in the form of Effectiveness Ratios, Efficiency Ratios, Routine Expenditure Ratios and Development Expenditure Ratios have been shown to influence the compliance of financial information disclosures. The results of this research do not support the research results of Chusna which states that the financial condition, level of dependence and prosperity of the region does not have a significant effect on the level of disclosure of information on regional financial management on the website (Chusna, 2016). The results of this research also refute the research results of Istikomah \& Mutmainah which states that the dependency ratio has a negative effect on the publication of regional government financial statements through the internet (Istikomah \& Mutmainah, 2017). Likewise, the research results conducted by Puspita and Martani which stated that regional performance described as the ratio of regional PAD and Expenditures did not affect the disclosure of content, presentation of disclosures, and total disclosure for regional government websites (Puspita \& Martani, 2012).

Based on the test results in table 4, it is known that the coefficient value of variable parameter of IFR accessibility is 0.749 with a significance level above 0.05 . These results indicate that empirically IFR accessibility does not affect the compliance of financial information disclosures. Accessibility IFR is the easy steps to obtain financial information from the official local government website. Even though there is an Instruction of the Minister of Home Affairs No. 188.52 / 1797 / SJ / 2012 which must be obeyed by local governments but the components on the local government website are still incomplete. As stated by Verawaty (2016), local governments have not been too serious in managing e-government, including in presenting financial reports as a form of public accountability.

The inconsistency of some of the research results above, it turns out, can be overcome by making IFR accessibility variables as moderating. With the existence of financial ratios that show high financial performance and are supported by the ease of accessing financial information, the compliance of financial information disclosure on the official website of the government will be higher. So the results of this research support the research results of Styles \& Tennyson's which states that cities with high per capita income and high levels of financial information disclosure will provide financial reports on the internet (Styles \& Tennyson, 2007). 
With good financial performance, high per capita income will encourage regional governments to provide financial information on the internet in full.

In the seventh hypothesis in this research, it was stated that the IFR Accessibility variable as moderating between the independence ratio to the compliance of financial information disclosure. After being statistically tested, the results of coefficient value of moderate variable parameter were at 0.002 with a significance level of 0.444 . This indicates that the IFR Accessibility variable is not moderated between the Independence Ratio and Compliance with financial information disclosures. The results showed that the ease of obtaining financial information (IFR accessibility) did not provide a stimulus for local governments to increase transparency in internet-based financial reporting. Dependence on the central government is an obstacle in realizing financial information disclosure in Indonesia.

Unlike the eighth hypothesis which reveals that IFR accessibility can moderate the effect of the effectiveness ratio on compliance with financial information disclosure, this hypothesis is accepted and can be proven statistically. The parameter coefficient value of effectiveness ratio variable is 0.066 with a significance level of 0.012 . This significance value is smaller than 0.05 so it can be concluded that IFR Accessibility is a moderation between the effectiveness ratio of compliance with financial information disclosure. Local governments that have tapped into all regional potentials to optimize revenue will make it easier to disclose financial information to the public through IFR accessibility. The public can easily get information on the effectiveness of regional finances which is a positive signal from the local government.

In the ninth hypothesis, IFR accessibility will be tested as moderating between efficiency ratios and compliance with financial information disclosures. Table 4 shows that the hypothesis can be accepted based on the results of the test obtained which is with a significance level of 0,000 , while the parameter coefficient value is -0.062 . So it can be concluded that IFR accessibility can moderate the effect of efficiency ratios on compliance with financial information disclosure. With easy access to financial information, the public can supervise the use of regional budgets while still paying attention to budget efficiency. Thus, local governments will be more transparent in managing regional spending.

In table 5, the data shows that the parameter coefficient value of the moderate variable is -0.001 and the significance level is 0.000 . This shows that IFR Accessibility is a moderating variable between the ratios of routine expenditure to compliance with financial information disclosure so that the research hypothesis can be accepted. The local government as the mandate holder of the community will be more transparent in the management of routine regional spending. When the budget realization report can be easily accessed by the public, the use of routine regional expenditure posts can be controlled so that local governments remain optimal in providing services to the public.

The eleventh hypothesis states that IFR accessibility can moderate the influence of the development expenditure ratio on compliance with financial information disclosures. The results of statistical tests show that the moderate coefficient value is 0.004 and the significance level is 0.000 . With a significance value that is smaller than 0.05 , it can be concluded that IFR accessibility is moderating between the development expenditure ratios to compliance with financial information disclosure. 
The ratio of development spending has a smaller portion than routine expenditure. Although small, development spending is made to provide services to the community in the form of facilities and infrastructure. Implementation of budgeted local government projects can be monitored through financial information on the official local government website. The transparency of the use of the budget will increase when local governments make this financial information a positive signal to get support from the public.

Thus from the 11th hypotheses proposed in this research, there are 3 hypotheses that are not statistically proven. The unacceptable hypotheses are $\mathrm{H} 1, \mathrm{H} 6$ and $\mathrm{H} 7$, while the other 8 hypotheses can be accepted empirically. The Independence ratio variable and IFR Accessibility variables do not directly influence the compliance of financial information disclosures. In addition, IFR Accessibility does not moderate the influence of the Independence Ratio on compliance with financial information disclosure.

In table 6, it can be seen that the magnitude of the adjusted $\mathrm{R}$ Square is 0.751 which means that $75,1 \%$ of disclosure compliance variation can be explained by independent variable of financial performance (including independence ratio, effectiveness ratio, efficiency ratio, routine expenditure ratio, and development expenditure ratio), independent variable of IFR accessibility and Moderate. The rest of $24,9 \%$ is explained by other factors outside the model.

Table 6. Determination Coefficient

\begin{tabular}{lll}
\hline Model & Adjusted R square & Conclusion \\
\hline 1 & .751 & $75,1 \%$ \\
\hline
\end{tabular}

\section{Conclusions}

Based on the results of the discussion, it can be concluded that Financial Performance and IFR Accessibility influence the Compliance of Financial Information Disclosure. It is partially proven that the ratio of effectiveness, efficiency ratio, ratio of routine expenditure and ratio of development spending affect compliance with financial information disclosure on the official government website. This proves that local governments have shown transparency in financial management. The financial information presented on the official government website is a form of accountability for the mandate that is held as a provincial-level executive agency. The community can control whether during the current period the regional government has optimally explored the regional potential to fulfill all regional expenditure effectively and efficiently. The use of budgets in routine expenditure items and development expenditures can be monitored by the public through a budget realization report published on the official local government website. So it is expected that there will be an increase in service quality and an increase in community welfare.

The existence of the internet that is easily accessed by the public to obtain financial information has a very large role in realizing transparency in public finances. Financial information that shows the financial performance of local governments is a positive signal for the community that will indirectly affect public support for the government itself. In order to achieve reliable internet accessibility, inexpensive facilities and infrastructure are required. Therefore, support from the central 
government is needed and the seriousness of local governments, to produce reliable financial information. This is why the independence ratio statistically has no effect on compliance with financial information disclosure.

This research has implications for the implementation of e-government policies for regional governments. Regional governments must begin to pay attention to the proportion of development expenditure compared to spending on consumptive interests. A successful e-government requires significant investment of funds for infrastructure and reliable human resources, so support from the central government is required. The successful implementation of e-government will provide great benefits, especially in terms of time and cost efficiency in disseminating information to the public. Similar research is needed to determine other factors that influence compliance with financial information disclosure in supporting financial transparency.

\section{References}

Anandayu, M. (2015). Analisis Komparasi Internet Financial Local Government Reporting pada Website Resmi Kabupaten dan Kota di Jawa Timur. repository.unej.ac.id, Universitas Jember, pp. 1-7.

Araujo, J. F., \& Romero, F. T. (2016). Local government transparency index: determinants of municipalities' rankings. International Journal of Public Sector Management, 29 (4), 327-347. https:// doi.org/10.1108/IJPSM-11-2015-0199

Bolivar, M. P., Munoz, L. A., \& Hernandez, A. M. (2013). Determinants of Financial Transparancy in Goverment, International Public Management Journal, 16(4), 557-602. https://doi.org/10.1080/10967494.2013.849169

Chaney, B. A., Mead, D. M., \& K Schermann, K. (2002). Financial reporting model: What it means for analyzing government financial condition. Journal of Government Financial Management Spring, pp. 27-31.

Chen, Y. N., Chen, H. M., Huang, W., \& Ching, R. K. H. (2006). E-Government Strategies in Developed and Developing Country: An Implementation Framework and Case Study. Journal of Global Information Management, 14(1), 23-46. https:/ / econpapers.repec.org/RePEc:igg:jgim00:v:14:y:2006:i:1:p:23-46.

Chusna, N. F. (2016). Determinan Tingkat Pengungkapan Informasi Pengelolaan Anggaran Daerah di Website Pemerintah Daerah. Master Thesis, Universitas Lampung, pp. 1-62.

Connelly, B. L., Certo, S. T., Ireland, R. D., Reutzel, \& Christopher S. (2011). Signalling Theory: A Review and Assesment. Journal of Management, 37(1), 39-67. https://doi.org/10.1177/0149206310388419

Elkadi, H. (2013). Success and failure factors for e-government projects: A case from Egypt. Egyptian Informatics Journal, 14 (2), 165-173, 2013. http:// dx.doi.org/10.1016/j.eij.2013.06.002

Guillamón, M.-D., et al. (2016). Factors influencing social media use in local governments: The case of Italy and Spain. Government Information Quarterly 12, 460-471. https:// doi.org/10.1016/j.giq.2016.06.005

Hadi, A., Handajani, L., \& Putra, I. N. (2018). Financial Disclosure based on Web-ICT Determinants: Its Implications for Local Government Financial Performance in Indonesia. International Research Journal of Management, IT \& Social Sciences, 5 (1), 72-85. https:/ /creativecommons.org/licenses/by-sa/4.0/ 
Halim, A. \& Damayanti, T. (2007). Seri Bunga Rampai Manajemen Keuangan Daerah. Yogyakarta: UPP STIM YKPN, pp. 262.

Hilmi, Z. A., \& Martani, D. (2012). Analysis of Factors Affecting the Level of Disclosure of Provincial Government Financial Statements. Proceeding of Simposium Nasional Akuntansi 15, Banjarmasin, ASPAK-17, (pp. 126).

Hiola, Y., Rosidi, \& Aji D.M. (2016). Political Environment In The Effect Of The Regional Government Financial Performance On Disclosure Of Financial Information On Website. Journal of Economics, Business, and Accountancy Ventura, 19(1), 27-36. http://dx.doi.org/10.14414/jebav.v19i1.442

Idris, A. L., Surasni, N. K., \& Irwan, M. (2018). The Determinant Disclosure of Internet Financial Reporting in District and City Government in Indonesia. Int.J.Eco. Res, 9(11), pp. 62-74. https://www.ijeronline.com/documents/volumes/2018/Jan\%20 \%20Feb\%2018/ijer\%20v9i1\%20jf(6).pdf

Indrajit, R. E. (2002). Electronic Government Strategi Pembangunan dan Pengembangan Sistem Pelayanan Publik Berbasis Teknologi Digital. Yogyakarta: Andi, (pp. 32-34).

Istikomah. \& Mutmainah, K. (2017). Determinants of Publication of Regional Government Financial Reports Through the Internet. Jurnal Ekonomi Kopertis VII, 12(1), pp. 1-17.

Khan, M. N., \& Ismail, N. A. (2012). Various Aspects of Internet Financial Reporting. Journal of Global Business and Economics, 4(1), 001-015. https://www.researchgate.net/publication/260126277

Mahsun, M. (2009). Pengukuran Kinerja Sektor Publik. Yogyakarta: BPFE, pp. 219-233.

Martani, D., \& Lestiani, A. (2012). Disclosure in local government financial statements : the case of Indonesia. Global review of Accounting and Finance, 3(1), 67-84. http://staff.ui.ac.id/system/files/users/martani/publication/22149pf-dwimartani.pdf

Mavlanova, T., Benbunan-Fich, R., \& Koufaris, M. (2012). Signalling Theory and Information Assymmetry in Online Commerce. Information and Management, 49(5), 240-247.

https://doi.org/10.1016/j.im.2012.05.004

Munyoka, Willard. (2019). Electronic Government Adoption in Voluntary Environment- a Case Study of Zimbabwe. ResearchGate Publication, July, 1-24. DOI: 10.1177/0266666919864713

Nosihana, A. \& Yaya, R. (2016). Internet Financial Reporting and Faktor-Faktor yang Memengaruhinya pada Pemerintah Kota dan Kabupaten di Indonesia. Jurnal Dinamika Akuntansi dan Bisnis, 3(2), 89-104. http://jurnal.unsyiah.ac.id/JDAB/article/view/5389

Puspita, R., \& Martani, D. (2012). Analisis Pengaruh Kinerja dan Karakteristik Pemda terhadap Tingkat Pengungkapan dan Kualitas Informasi dalam Website Pemda. Proceeding of Simposium Nasional Akuntansi 15, Banjarmasin, September, 20-23. Pusat Data Ekonomi dan Bisnis, 15, (pp. 1-25).

Reffat, R. M. (2006). Developing a Successfull e-government. University of Sidney NSW, Australia, (pp. 1-13).

Rusmin, Astami, E. W., \& Scully, G. (2014). Local Government Units in Indonesia: Demographic Attributes and Differences in Financial Condition. Australasian Accounting, Businessand Finance Journal, 8(2), pp. 88109. http://dx.doi.org/10.14453/aabfj.v8i2.7 
Styles, A. K., \& Tennyson, M. (2007). The Accessibility of Financial Reporting of US Municipalities on the Internet. Journal of Public Budgeting, Accounting and Financial Management, 19(1), 56-92, Spring.

Verawaty, (2016). The Comparative Analysis of Accesibility Index Value of Government Internet Financial Reporting in Indonesia. Applied Finance and Accounting, 2(2), pp. 1-10. http://afa.redfame.com

Verawaty. (2015). Determinants of Internet Accessibility Financial Reporting through Local Government E-Government in Indonesia. Proceeding of Simposium Nasional Akuntansi 18, Medan, (pp. 1-25).

Wau, I., \& Ratmono. (2015). Analisis Faktor-Faktor Yang Mempengaruhi Ketersediaan Dan Keteraksesan Internet Financial Reporting Oleh Pemerintah Daerah. Diponegoro Journal of Accounting, 4(4), 1-12. http:/ / ejournals1.undip.ac.id/index.php/accounting

Zimmerman, J. (1977). The Municipal Accounting Maze: An Analysis of Political Incentives. Journal of Accounting Research, 15, 107-144. DOI: 10.2307/2490636 https://www.jstor.org/stable/2490636

\section{About the Author}

\section{Anissa Windarti}

Lecturer and researcher at Department of Social Science Education at Universitas Islam Negeri Syarif Hidayatullah Jakarta. She graduated from Gadjah Mada University specialty "Public Sector Accounting". Her fields of scientific activity are public sector accounting, information system, taxation, social science. 